\title{
Pendampingan Teman Sebaya dan Peran Orangtua dalam Mewujudkan Remaja Bebas Narkoba dan Sehat Reproduksi di Wilayah Pesisir
}

\author{
Fitriani Pramita Gurning ${ }^{\mathrm{a}^{*}}$, Fauziah Nasution $^{\mathrm{b}}$, Eliska $^{\mathrm{c}}$ \\ Fakultas Kesehatan Masyarakat, Universitas Islam Negeri Sumatera Utara, Medan 20235, Indonesia \\ afitrianigurning@uinsu.ac.id; bfauziahnasution@uinsu.ac.id*; celiska@uinsu.ac.id \\ * corresponding author
}

ARTICLE INFO

Keywords

Counseling

Peer education

Assistance

Youth

\begin{abstract}
The frequent occurrence of drug abuse and premarital sex which is indicated from the frequent occurrence of raids on drug cases in Langkat District, the high number of early childhood marriages that still occur. This is compounded by the inactivity of religiously oriented adolescent activities, where previously youth groups tended to be active in empowering adolescents. School is one of the places for adolescent interaction and in one day many teenagers spend their time in school. The form of community facilitation activities with counseling activities, peer education training and mentoring through whatup media groups and also conducting counseling to parents aimed at increasing the knowledge and role of parents as agents of socialization to adolescents, peer education training aimed at increasing the role of adolescents as peer educators and assistance aimed at assisting adolescent peer educators in planning for, and dealing with problems related to the dangers of drugs, HIV/AIDS and reproductive health. An increase in students' knowledge after getting counseling and training about the dangers of drugs, HIV/AIDS and adolescent reproductive health. Suggestions for further activities are the need for traning of trainers for adolescent doctors and assistance in making adolescent health programs.
\end{abstract}

\section{Pendahuluan}

Perkembangan zaman saat ini sudah memasuki era bersatunya seluruh negara-begera ke dalam sebuah sistem bersama. Sebuah sistem yang tidak lagi terpisahkan oleh batas-batas negara, dimana semua dapat diakses dengan mudah melalui kemajuan teknologi. Sistem tersebut bernama globalisasi. Kondisi tersebut ditandai dengan bertemunya arus kebudayaan dan sosial yang lintas dunia, sehingga tak jarang budaya-budaya yang ada di luar negeri dapat masuk ke negara kita. Tentu saja ada yang positif dan ada juga yang negatif. Salah satu yang paling nampak pengaruhnya adalah pada kelompok usia remaja.

Masa remaja merupakan masa peralihan dari anak-anak ke masa dewasa. Kehidupan remaja merupakan kehidupan yang sangat menentukan bagi kehidupan masa depan mereka selanjutnya. Pada tahun 2018 jumlah remaja umur 10-24 tahun sangat besar yaitu sekitar 70,49 juta atau 26,6\% dari jumlah Penduduk Indonesia sebanyak 265 juta jiwa [1].

Banyak penelitian sudah dilakukan dan menunjukkan bahwa remaja mempunyai permasalahan yang sangat kompleks karena beriringan dengan perkembangan kehidupannya memasuki masa transisi. Masalah yang menonjol pada remaja adalah permasalahan seputar Seksualitas, HIV dan AIDS serta Napza, rendahnya pengetahuan remaja tentang Kesehatan 
Reproduksi Remaja dan usia normal untuk kawin pertama perempuan relatif masih rendah yaitu 19,8 tahun [2].

Berdasarkan laporan SDKI 2017 tentang pengalaman seksual remaja, secara umum, ada satu persen dari keseluruhan remaja wanita yang dilaporkan pernah melakukan hubungan seksual . Sedangkan remaja pria yang pernah melakukan hubungan seksual lebih tinggi daripada wanita yaitu 8 persen. Dampak terburuk yang muncul karena seks pranikah cukup pelik, misalnya kehamilan yang tidak diinginkan yang berakhir pada kejadian abortus, rusaknya kehidupan sosial remaja karena berkeluarga sebelum waktunya.

Kemudian berdasarkan laporan Badan Narkotika Nasional tahun 2016, menunjukkan bahwa jumlah pengguna Napza pada tahun 2016 mencapai 115.404. Dimana 51.986 dari total pengguna adalah mereka yang berusia remaja (usia 16-24 tahun). Mereka yang pelajar sekolah berjumlah 5.484 dan mahasiswa berjumlah 4.055. Begitu juga dengan kasus HIV sampai dengan September 2011 sebesar 71.437 kasus. Untuk kasus AIDS secara kumulatif jumlah kasus AIDS sampai dengan September 2017 sebesar 25.936 kasus. Dari jumlah kasus tersebut, 45,9\% diantaranya adalah kelompok usia 20-29 tahun [3]. Unicef (2017) menyatakan bahwa Remaja bertanggung jawab atas hampir seperlima kasus HIV baru di tahun 2017, yang menunjukkan perlunya strategi dan program pencegahan untuk kelompok rentan ini [4].

Selain itu, berdasarkan Survei Kesehatan Rumah Tangga Indonesia tahun 2017 diketahui bahwa pengetahuan remaja tentang cara paling penting untuk menghindari infeksi HIV masih teegolong rendah, sebab hanya $14 \%$ remaja perempuan dan $95 \%$ remaja laki-laki menyebutkan pantang berhubungan seks, $18 \%$ remaja perempuan dan $25 \%$ remaja laki-laki menyebutkan menggunakan kondom serta $11 \%$ remaja perempuan dan $8 \%$ remaja laki-laki menyebutkan membatasi jumlah pasangan (jangan berganti-ganti pasangan seksual) sebagai cara menghindari HIV dan AIDS.

Hal yang menjadi penyebab masalah perilaku seksual remaja, seperti remaja melakukan hubungan seksual pranikah ini adalah kurangnya pemahaman dan penerapan ilmu agama yang dimiliki remaja dalam kehidupan sehari-hari, masalah ekonomi, kurangnya pendidikan seksual ataupun kesehatan reproduksi dari keluarga yang merupakan tempat belajar pertama dari remaja, sehingga remaja yang berada dalam masa transisi memiliki keingintahuan yang besar, akan mencari sendiri informasi yang dibutuhkannya melalui media sosial. Seringkali informasi yang diperoleh remaja ini tidak benar dan memberikan pengaruh yang tidak baik bagi perkembangan remaja, selain itu peran orang tua juga turut mempengaruhi perilaku seksual remaja [5].

Berdasarkan laporan Ditjen PP\&PL Kementerian Kesehatan RI (2017) bahwa hingga tahun 2017, secara akumulatif penderita HIV /AIDS di Kabupaten Langkat merupakan salah satu daerah yang tinggi dengan kasus narkoba di Sumatera Utara [5].

Provinsi Sumatera Utara memiliki banyak kabupaten/ kota termasuk kota stabat kabupaten langkat yang juga banyak penggunaan narkoba. Selama 2017, tindak pidana kasus narkotika di Kabupaten Langkat mengalami peningkatan signifikan yaitu 195 kasus narkoba dengan 284 tersangka, terdiri dari pengguna atau pemakai maupun pengedar dan diantaranya terdapat laki-laki, wanita, dan anak-anak remaja. Berdasarkan data tersebut diperlukannya upaya-upaya yang strategis dalam penanganan kasus narkoba ini bukan dari parat penegak hukum saja melainkan dari teman sebaya dan peran orang tua [6].

Dari 23 kecamatan yang ada di Kabupaten Langkat, Kecamatan Secanggang, Tanjung Pura, Gebang, Babalan dan Pangkalan Susu merupakan daerah pesisir pantai di Kabupaten Langkat, dengan penduduk asli Melayu, dan suku lainnya seperti Jawa, Batak dan Karo. Berdasarkan data Pelayanan Kesehatan Peduli Remaja (PKRR) Puskesmas Secanggang tahun 2017 terdapat masalah kesehatan remaja diantaranya masalah seksual remaja, kenakalan remaja, penggunaan lem dan obat-obat terlarang, serta kehamilan pada remaja yang meningkat dari tahun 2015 dengan jumlah 18 kehamilan remaja menjadi 23 pada tahun 2017.

Sekolah merupakan suatu wadah dalam berinteraksi kelompok remaja yang menghabiskan waktu selama sehari di sekolah. MAN 2 Tanjung Pura merupakan salah satu sekolah favorit yang ada di Langkat. Dimana siswa berasal banyak dari daerah pesisir pantai seperti Kecamatan Secanggang dan Tanjung Pura. Siswa di MAN 2 Tanjung Pura banyak yang aktif di kegiatan organisai desa seperti remaja masjid, angora Badan Kenaziran Mesjid (BKM) dan Karang Taruna. 
Apabila perilaku remaja yang tidak sehat ini terus berlangsung, tentu akan mengganggu tugas-tugas pertumbuhan dan perkembangan kehidupan remaja, baik secara individual maupun sosial. Oleh karena itu perlu dilakukan sebuah upaya yang bersifat kontinyu dan bersifat memberdayakan masyarakat dari semua lapisan dan kelompok umur dalam sebuah kegiatan untuk mengatasi permasalahan yang ada [7].

\section{Metode}

Metode pelaksanaan mencakup urutan atau tata cara pelaksanaan pendampingan mulai dari pendekatan yang dipergunakan, teknik pengumpulan, pengelolaan dan analisis data. adapun pendekatan yang akan digunakan dalam kegiatan ini dapat dilihat pada matriks berikut ini:

a. Penyuluhan tentang Narkoba, HIV/AIDS dan Kespro pada remaja. Materi akan disampikan langsung oleh Tim kegiatan ini Metode yang akan digunakan adalah ceramah dengan bantuan slide presentasi.

b. Pelatihan pendidik Sebaya, metode yang digunakan adalah pelatihan. Dalam pelatihan ini mitra akan dilatih untuk mengetahui semua hal mengenai penyalahgunaan narkoba, HIV/AIDS dan Kespro pada remaja. Berbagai metode yang diterapkan antara lain, ceramah, simulasi, diskusi kelompok, role play, dan latihan.

c. Pendampingan, kegiatan ini dilakukan dengan pendampingan dengan pendekatan micro sharing dan teaching melalui group Whatsapp [8].

\section{Hasil dan Diskusi}

Dalam kegiatan ini pendidikan teman sebaya bukan hanya penyuluhan tentang bahaya narkoba, HIV/AIDS dan kesehatan reproduksi di lingkup komunitas remaja tetapi juga memberikan bentuk pendekatan dan pendampingan setelah dilakukannya penyuluhan melalui group whatzup teman sebaya selama tiga minggu pendampingan melalui group WA. Remaja tingkat menengah menjadi sasaran untuk pendekatan dan pendampingan dalam mewujudkan remaja bebas narkoba, HIV/AIDS dan kesehatan reproduksi, dengan tujuan remaja dapat memberikan informasi dengan sesame remaja lainnya baik di lingkungan sekolah maupun rumah [9].

\section{a. Penyuluhan tentang Narkoba, HIV/AIDS dan Kespro pada remaja}

Kegiatan ini dilakukan pada hari rabu tanggal 28 Agustus 2019 mulai pukul 09.00 s.d pukul 17.00 WIB. Lokasi penyuluhan dilakukan di MAN 2 Tanjung Pura kelas X, XI dan XII jumlah keseluruhan 93 siswa. Penyuluhan dilakukan dengan bantuan slide presentasi tentang topiktopik berkaitan dengan narokoba, HIV/AIDS, dan kesehatan reproduksi.

Pemateri selain anggota tim, juga berasal dari pihak lain yang kompeten dan bekerjasama dengan pihak kampus. Metode pelaksanaan penyuluhan dilakukan dengan metode ceramah dan role play. Adapun jadwal pemberian materi adalah sebagai berikut:

Tabel 1. Uraian Kegiatan Penyuluhan tentang Bahaya Narkoba, HIV-AIDS dan Kesehatan Reproduksi Remaja

\begin{tabular}{lll}
\hline No. & \multicolumn{1}{c}{ Waktu } & \multicolumn{1}{c}{ Materi } \\
\hline 1. & $09.00-10.00$ & Siswa mengerjakan soal pre test \\
2. & $10.00-11.00$ & Penyuluhan materi Bahaya Narkoba \\
3. & $11.00-12.00$ & Penyuluhan materi HIV/ AIDS \\
4. & $12.00-14.00$ & I S H O M A \\
5. & $14.00-15.00$ & Penyuluhan materi kesehatan reproduksi \\
6. & $15.00-16.00$ & Pelaksanaan post test \\
\hline
\end{tabular}

Hasil dari pre test dan post test terdapat peningkatan pengetahuan siswa kelas X, XI dan XII, setelah mendapatkan penyuluhan tentang bahaya narkoba, HIV/AIDS dan kesehatan reproduksi remaja, berdasarkan hasil pre test skor yang didapat $\leq 75 \%$ sebanyak seluruh peserta tinggat pengetahuan rendah bahaya narkoba, HIV/AIDS dan kesehatan reproduksi remaja dan setelah diberikan penyuluhan terjadi peningkatan pengetahuan siswa. Dapat dilihat pada tabel berikut ini: 
Tabel 2. Distribusi Frekuensi Pengetahuan Peserta Pre dan Post Test Penyuluhan Pendidikan Teman Sebaya

\begin{tabular}{lcc}
\hline \multicolumn{1}{c}{ Pengetahuan } & Frekuensi & \% \\
\hline Kelas X MIPA 1 & & \\
\hline Baik $(\geq 75 \%)$ & 30 & 88 \\
Kurang Baik $(\leq 75 \%)$ & $\mathbf{3 4}$ & $\mathbf{1 0 0}$ \\
\hline Jumlah & & 68 \\
\hline Kelas XI Agama & 23 & 32 \\
\hline Baik $(\geq 75 \%)$ & 11 & $\mathbf{1 0 0}$ \\
Kurang Baik $(\leq 75 \%)$ & $\mathbf{3 4}$ & \\
\hline Jumlah & & 68 \\
\hline Kelas XII IPS 2 & 17 & 32 \\
\hline Baik $(\geq 75 \%)$ & 8 & $\mathbf{1 0 0}$ \\
Kurang Baik $(\leq 75 \%)$ & $\mathbf{2 5}$ & \\
\hline Jumlah & & \\
\hline
\end{tabular}

Meningkatnya pengetahuan siswa setelah diberikan penyuluhan membuktikan bahwa informasi tentang bahaya narkoba, HIV/AIDS, dan kesehatan reproduksi yang diberikan dapat diterima oleh siswa. Dan selanjutnya akhir sesi peserta diminta secara bersama untuk menyusun rencana aksi dalam mengatasi bahaya narkoba, HIV/AIDS, dan kesehatn Reproduksi yang akan dilanjutkan dalam kegiatan pendampingan [10].

\section{b. Pelatihan Pendidik Sebaya}

Kegiatan pelatihan ini dilakukan pada hari kamis tanggal 10 Oktober 2019 dimulai dari pukul 09.00 sampai pukul 16.00. Peserta pelatihan ini adalah siswa MAN 2 Tanjung Pura kelas X, XI dan XII yang mengikuti penyuluhan yang dilakukan sebelumnya. Materi pelatihan pendidikan sebaya adalah sebagai berikut:

Tabel 3. Uraian Kegiatan Pelatihan Pendidikan Teman Sebaya di MAN 2 Tanjung Pura

\begin{tabular}{cl}
\hline \multicolumn{1}{c}{ Waktu } & \multicolumn{1}{c}{ Uraian Kegiatan } \\
\hline $09.00-12.00$ & $\begin{array}{l}\text { Para peserta membagikan pengalaman seputar masalah narkoba, HIV-AIDS } \\
\text { dan Kesehatan reproduksi di lingkungannya }\end{array}$ \\
$12.00-14.00$ & I S H O M A \\
$14.00-15.00$ & $\begin{array}{l}\text { Fasilitator memberikan tugas pada peserta untuk memberikan pemecahan } \\
\text { masalah dari permasalahan-permasalahan tentang narkoba, HIV-AIDS dan } \\
\text { kesehatan reproduksi } \\
\text { Beberapa siswa memaparkan uraian pemecahan masalah yang telah } \\
\text { didiskusikan bersama dalam kelompok. }\end{array}$ \\
\hline
\end{tabular}

Metode yang digunakan dalam pelatihan ini adalah metode kerucut Edgar Dale yaitu metode yang informative diterima sehingga lebih mudah diserap dan diingat dengan materi yang diberikan dalam bentuk berbagi pengalaman, dibandingkan bentuk lisan, tulisan atau gambar saja. Selain itu ditambahkan pula pendukung pemberian informasi melalui media booklet yang diberikan kepada siswa seputar narkoba, HIV-AIDS dan kesehatan reproduksi sehingga diharapkan dapat mempermudah pemahaman remaja mengenai kesehatan.

Evaluasi kegiatan pelatihan pendidikan teman sebaya dilakukan dengan menggunakan pre test dan post test dimana hasil dari pre test dan post test yang dilakukan memiliki kedua hasil ini memiliki hasil nilai $\geq 75 \%$, dapat dilihat pada tabel berikut ini: 
Tabel 4. Distribusi Frekuensi Pengetahuan Peserta Pre dan Post Test Pelatihan Pendidikan Teman Sebaya

\begin{tabular}{|c|c|c|c|c|}
\hline Pengetahuan & Pre Test & & Post Test & \\
\hline & Frekuensi & $\%$ & Frekuensi & $\%$ \\
\hline \multicolumn{5}{|l|}{ Kelas X MIPA 1} \\
\hline Baik $(\geq 75 \%)$ & 31 & 88 & 33 & 99 \\
\hline $\begin{array}{l}\text { Kurang } \\
(\leq 75 \%)\end{array}$ & 3 & 12 & 1 & 1 \\
\hline Jumlah & 34 & 100 & 34 & 100 \\
\hline \multicolumn{5}{|l|}{ Kelas XI Agama } \\
\hline Baik $(\geq 75 \%)$ & 26 & 76 & 30 & 88 \\
\hline $\begin{array}{l}\text { Kurang } \\
(\leq 75 \%)\end{array}$ & 8 & 24 & 4 & 1219 \\
\hline \multicolumn{5}{|l|}{ Lanjutan Tabel 4.4. } \\
\hline Jumlah & 34 & 100 & 34 & 100 \\
\hline \multicolumn{5}{|l|}{ Kelas XII IPS 2} \\
\hline Baik $(\geq 75 \%)$ & 20 & 68 & 21 & 68 \\
\hline $\begin{array}{l}\text { Kurang Baik } \\
(\leq 75 \%)\end{array}$ & 5 & 32 & 4 & 32 \\
\hline Jumlah & 25 & 100 & 25 & 100 \\
\hline
\end{tabular}

\section{c. Pendampingan}

Pendampingan akan dilakukan rutin selama 3 bulan, dimulai pada tanggal 29 Agustus 2019 sampai 29 November 2019 melalui group Teman Sebaya Whatssupdengan sharing informasi seputar narkoba, HIV/ AIDS dan Kesehatan reproduksi remaja. Metode yang digunakan dalam kunjungan menggunakan pendekatan dengan pendekatan micro sharing dan teaching.

Pemantauan yang dilakukan setelah melakukan pendampingan melalui group whatsup, siswa/ remaja di awal pendampingan sudah menunjukkan respon yang cukup baik terkait dengan narkoba HIV/AIDS dan Kesehatan reproduksi remaja [11].

Proses pendampingan dilakukan dengan memberikan informasi seputar bahaya narkoba, HIV-AIDS dan kesehatan reproduksi, selain itu para siswa juga dapat menanyakan atau sharing pengalaman seputar bahaya narkoba, HIV/AIDS dan kesehatan reproduksi. Sekitar $75 \%$ siswa kelas X, XI dan XII cukup aktif untuk berpartisipasi dalam group pendampingan melalui whatsapp.

\section{d. Peran Orangtua}

Kegiatan yang dilakukan dalam memberikan pengetahuan tentang bahaya narkoba, HIVAIDS dan kesehatan reproduksi remaja dilakukan atas bantuan pihak sekolah dengan bantuan komite sekolah, adapun peserta dalam kegiatan ini adalah orang tua murid yang telah mendapatkan penyuluhan, pelatihan dan pendampingan pendidikan sebaya. Kegiatan dilakukan pada hari jumat tanggal 29 September 2019 yang dilakukan di rumah salah satu orang tua murid dengan jumlah peserta yang hadir hanya 21 orang.

Awal kegiatan ini dilakukan penyuluhan tentang bahaya narkoba, HIV-AIDS dan kesehatan reproduksi remaja, tanya jawab serta dialog dengan orang ta murid seputar masalah bahaya narkoba, HIV-AIDS dan kesehatan reproduksi remaja. Adapun tujuan dari kegiatan ini adalah agar orang tua dapat memberikan nasihat dan menjaga anaknya dari ancaman narkoba, HIVAIDS dan kesehatan reproduksi remaja.

\section{Kesimpulan}

Beberapa hal yang dapat disimpulkan dari hasil kegiatan pendampingan komunitas adalah sebagai berikut:

1. Pengetahuan siswa tentang bahaya narkoba, HIV-AIDS dan kesehatan reproduksi remaja dapat meningkat dengan dilakukannya penyuluhan kesehatan. 
2. Pemahaman siswa tentang bahaya narkoba, HIV-AIDS dan kesehatan reproduksi remaja sampai dengan membuat pemecahan masalah dapat meningkat dengan dilakukannya pelatihan pendidikan sebaya.

3. Pengetahuan orang tua tentang bahaya narkoba, HIV-AIDS dan kesehatan reproduksi remaja dapat meningkat dengan dilakukannya penyuluhan kesehatan.

\section{Saran} berikut:

Beberapa saran yang dapat diuraikan dari pendampingan komunitas ini adalah sebagai

1. Perlu adanya kegiatan rutin dalam peningkatan pengetahuan siswa tentang bahaya narkoba, HIV-AIDS dan khususnya kesehatan reproduksi remaja yang diberikan pihak sekolah atau UKS.

2. Perlu adanya kegiatan selanjutnya untuk memberikan pelatihan (Training of Trainer) untuk dokter remaja sekolah.

3. Kegiatan selanjutnya perlu memberikan pelatihan pembuatan program Usaha Kesehatan Sekolah

\section{Referensi}

[1] Sensus Penduduk Indonesia Tahun 2017

[2] Survei Demografi Kesehatan Indonesia Tahun 2017

[3] BKKBN. (2017). Pedoman Pengelolaan Pusat Informasi dan Konseling Remaja dan Mahasiswa (PIK Remaja/Mahasiswa). Jakarta

[4] Unicef. (2017). Unicef Indonesia : Laporan Tahunan 2012. Unicef Indonesia. Jakarta

[5] Kementerian Kesehatan RI. 2017. Perkembangan HIV/AIDS di Tahun 2013. PP\&PL Kementerian Kesehatan RI. Jakarta

[6] Aisyaroh, N. (2009). Kesehatan Reproduksi Remaja, Jurnal Majalah Ilmiah Sultan Agung Diterbitkan oleh Unissula

[7] Karakternews, (2017). http://karakternews.com/hukum-kriminal/hukum/polres-deli-serdangringkus-79-pengedar-narkoba. Diakses 25 April 2015 pukul 23.00

[8] Mappiare, A. (1990). Psikologi remaja. Surabaya : Percetakan Usaha Nasional.

[9] Survei Demografi Kesehatan Indonesia Tahun 2016

[10] Survei Kesehatan Rumah Tangga Indonesia Tahun 2017

[11] Gunawan R, Pratama M, Sulaiman, Anggriani, Gurning F. (2018). Increasing Of HIV/AIDS Prevention And Drugs Through Whatsapp Based Training And Assistance In Adolescents In Batang Kuis Deli Serdang District. International Journal of Scientific and Engineering research. Vol. 9 (9). 